\title{
FAKTOR-FAKTOR YANG MEMPENGARUHI PELAKSANAAN PELAYANAN ANTENATAL CARE TERPADU PADA BIDAN DI PUSKESMAS KOTA PEKALONGAN
}

\author{
Ana Setyowati ${ }^{1}$, Ni'matul Ulya $^{2}$, U mmi Sa' adah $^{3}$ \\ E mail: anena.nenaza@gmail.com \\ DIII/ IV AKBID Harapan Ibu Pekalongan \\ Jl. Sriwijaya No. 7 Pekalongan \\ Telp/Fax (0285) 4416108
}

\begin{abstract}
Abstrak
Pelayanan antenatal merupakan pelayanan yang diterima wanita selama kehamilan dan sangat penting dalam membantu memastikan bahwa ibu dan janin selamat selama kehamilan dan persalinan. Pendekatan pelayanan antenatal ditekankan pada kualitas bukan kuantitas pada saat kunjungan.

Salah satu faktor yang berpengaruh terhadap tingginya angka kematian ibu adalah sikap dan perilaku ibu itu sendiri selama hamil dan didukung oleh pengetahuan ibu terhadap kehamilannya. Penelitian ini bertujuan untuk menggambarkan faktor-faktor yang mempengaruhi pelaksanaan ANC terpadu oleh bidan di Puskesmas.

Penelitian ini dilakukan dengan menggunakan metode penelitian kualitatif. Informasi dalam penelitian kualitatif dikumpulkan dengan menggunakan pedoman wawancara yang tidak dapat dianalisis menggunakan teknik statistic. Sampel dalam penelitian ini bukan dinamakan responden, tetapi sebagai subyek atau informan dalam penelitian. Subyek dalam penelitian ini adalah bidan koordinator di Puskesmas Kota Pekalongan Prosedur pengambilan subyek dalam penelitian ini menggunakan cara atau metode purposive yaitu didasarkan pada suatu pertimbangan tertentu tanpa mengandalkan kriteriakriteria statistik

Hasil wawancara mendalam terhadap 4 informan utama dan 4 informan triangulasi dapat disimpulkan bahwa sebagian bidan mengetahui tujuan dan manfaat dari standar pelayanan antenatal. Adapun tujuan dari standar pelayanan antenatal adalah memudahkan pelayanan antenatal, bekerja sesuai aturan dan standar sedangkan manfaat dari standar pelayanan antenatal adalah kerja dapat terlindungi, ibu dan janin dapat terdeteksi secara dini bila ada kelainan, pelayanan lebih berkualitas, meningkatkan pelayanan dan pelayanan menjadi aman

Diharapkan seluruh Puskesmas melaksanakan pelayanan ANC Terpadu yang dilakukan oleh bidan dan dapat memanfaatkan alat yang telah tersedia untuk meningkatkan pelayanan ANC terpadu sesuai dengan standar
\end{abstract}

Kata Kunci: Pelaksanaan Pelayanan ANC

\section{Pendahuluan}

Program kesehatan ibu dan anak merupakan salah satu prioritas utama pembangunan kesehatan Indonesia untuk menurunkan kematian dan kejadian sakit di kalangan ibu, bayi dan anak. Dewasa ini angka kematian ibu dan bayi di Indonesia masih tinggi dibandingkan dengan Negara ASEAN yang lain dan upaya penanggulangannya cukup rumit. Oleh Karena itu, Angka Kematian Ibu (AKI) dan Angka Kematian Bayi (AKB) di Indonesia masih merupakan masalah kesehatan masyarakat dan salah satu indikator terpenting untuk menilai kualitas pelayanan Kesehatan Ibu dan Anak (KIA). ${ }^{1}$

Faktor yang berkontribusi terhadap kematian ibu, secara garis besar dapat dikelompokkan menjadi penyebab langsung dan penyebab tidak langsung. Penyebab langsung kematian ibu adalah faktor yang berhubungan dengan komplikasi kehamilan, persalinan dan nifas seperti perdarahan, pre eklampsia / eklampsia, infeksi, persalinan macet dan abortus. Penyebab tidak langsung kematian ibu adalah faktor-faktor yang memperberat keadaan ibu hamil seperti EMPAT TERLALU (terlalu muda, 
terlalu tua, terlalu sering melahirkan dan terlalu dekat jarak kelahiran) ${ }^{1,2}$

Selain itu masih terdapat masalah dalam penggunaan kontrasepsi. Angka unmet-need $\quad 9,1 \%$. Kondisi ini merupakan salah satu factor penyebab terjadinya kehamilan yang tidak diinginkan dan aborsi yang tidak aman yang pada akhirnya dapat menyebabkan kesakitan dan kematian ibu). Malaria pada kehamilan seringkali menimbulkan komplikasi yang berbahaya bagi ibu, janin dan bayinya.

Sifilis merupakan salah satu infeksi menular seksual yang juga perlu mendapat perhatian. Ibu hamil yang menderita sifilis berpotensi untuk melahirkan bayi dengan sifilis congenital. Data terbatas dari 3 kabupaten model, dari 2.640 ibu hamil diperiksa yang positif 52 ibu hamil $(1,97 \%){ }^{2}$

Penyakit kronis seperti hipertensi, diabetes mellitus, jantung, asma berat, dan gangguan jiwa sangat mempengaruhi kondisi kesehatan ibu, janin dan bayi baru lahir. Penanganan penyakit kronis ini belum masih seperti yang diharapkan dan datanya juga belum terekam dengan baik. ${ }^{4}$

Masalah gizi yang lain adalah kurang energy kronik (KEK) dan konsumsi garam beryodium yang masih rendah. Wanita usia subur (WUS) yang beresiko KEK sekitar 13,6\% dan hanya $62,3 \%$ rumah tangga yang mengkonsumsi garam beryodium cukup. $^{3}$

Untuk mengatasi permasalahan tersebut diatas, maka pelayanan antenatal difasilitas kesehatan pemerintah maupun swasta dan praktik perorangan/kelompok perlu dilaksanakan secara komprehensif dan terpadu mencakup upaya promotif, preventif, sekaligus kuratif dan rehabilitative yang meliputi pelayanan KIA, gizi, pengendalian penyakit menular (imunisasi, HIV/AIDS, TB, malaria, penyakit menular), penanganan penyakit tidak menular serta beberapa program local dan spesifik lainnhya sesuai dengan kebutuhan program. ${ }^{1}$

Pelayanan ANC terpadu merupakan pelayanan antenatal komprehensif dan terpadu, mencakup upaya promotif, preventif, sekaligus kuratif dan rehabilitatif, yang meliputi pelayanan KIA, gizi, pengendalian penyakit menular (imunisasi, HIV/AIDS, malaria, penyakit menular seksual), penanganan penyakit tidak menular serta beberapa program lokal dan spesifik lainnya sesuai dengan kebutuhan program.

Harapan pelayanan antenatal terpadu yaitu untuk mengajak kembali ke pelayanan yang terarah, sesuai dengan tujuan yang akan memberikan kerangka pelayanan antenatal yang efektif. Dari studi pendahuluan yang dilakukan dengan wawancara terhadap bidan puskesmas mengatakan bahwa mereka belum melakukan pelayanan antenatal terpadu secara komprehensif dikarenakan belum lengkapnya sarana dan prasarana di Puskesmas. ${ }^{5}$

Tujuan dalam penelitian ini adalah mengetahui hubungan Faktor-Faktor Yang Mempengaruhi Pelaksanaan ANC Terpadu Pada Bidan Puskesmas Di Kota Pekalongan.

Menurut Ikatan Bidan Indonesia (IBI), bidan diakui sebagai tenaga profesional yang bertanggungjawab dan akuntable, yang bekerja sebagai mitra perempuan untuk memberikan dukungan, asuhan dan nasehat selama hamil, masa persalinan dan masa nifas, memimpin persalinan atas tanggung jawab sendiri dan memberikan asuhan kepada bayi baru lahir, dan bayi. Asuhan ini mencakup upaya pencegahan, promosi persalinan normal deteksi komplikasi pada ibu dan anak,dan akses bantuan medis atau bantuan lain yang sesuai, serta melaksanakan tindakan kegawatdaruratan. ${ }^{1}$ 
Bidan mempunyai tugas penting dalam konseling dan pendidikan kesehatan, tidak hanya kepada perempuan, tetapi juga kepada keluarga dan masyarakat. Kegiatan ini harus mencakup pendidikan antenatal dan persiapan menjadi orang tua serta dapat meluas pada kesehatan perempuan, kesehatan seksual atau kesehatan reproduksi dan asuhan anak. Bidan dapat praktik diberbagai tatanan pelayanan, termasuk di rumah, masyarakat, Rumah Sakit, klinik atau unit kesehatan lainnya.

Pelayanan Antenatal Care merupakan langkah identifikasi medis dan psikologis yang mungkin dapat mempengaruhi kesehatan maternal dan perinatal serta mengurangi adanya komplikasi tak terdeteksi yang dapat menyebabkan konsekuensi serius bagi ibu dan bayi. ${ }^{6} \quad$ Intervensi esensial dalam ANC adalah identifikasi dan manajemen komplikasi obstetric seperti preeklamsi, imunisasi tetanus toksoid, penanganan pencegahan intermitten untuk malaria, manajemen infeksi HIV, sipilis dan penyakit menular seksual lainnya. ANC juga merupakan wadah edukasi bagi ibu hamil dan keluarga mengenai pentingnya asupan makanan yang adekuat, mengurangi pekerjaan yang berat, serta dukungan emosional yang adekuat dari keluarga untuk ibu hamil. ${ }^{7,8}$

\section{Metode Penelitian}

Penelitian ini dilakukan dengan menggunakan metode penelitian kualitatif. Subyek dalam penelitian ini adalah bidan koordinator di Puskesmas Kota Pekalonga. Prosedur pengambilan subyek dalam penelitian ini menggunakan cara atau metode purposive Obyek penelitian kualitatif yaitu apa yang menjadi sasaran penelitian dalam hal ini adalah faktorfaktor yang mempengaruhi pelaksanaan ANC terpadu. Subyek atau informan utama dalam penelitian ini adalah 4 bidan koordinator di Puskesmas Kota
Pekalongan dan triangulasi adalah 4 kepala puskesmas di Kota pekalongan. Pengumpulan data dalam penelitian ini menggunkan wawancara mendalam kepada 4 kepala puskesmas kota pekalongan. ${ }^{6}$

\section{Hasil dan Pembahasan}

Gambaran karakteristik responden Hasil pengumpulan data primer yang berasal dari informan Utama diperoleh gambaran karakteristik yang meliputi umur, pendidikan dan masa kerja.

Tabel 4.1 Gambaran Karakteristik Informan Bidan

\begin{tabular}{|l|l|l|l|l|l|}
\hline No & $\begin{array}{l}\text { Kode } \\
\text { Respon } \\
\text { den }\end{array}$ & $\begin{array}{l}\text { Umu } \\
\text { (thn) }\end{array}$ & Jabatan & Pendidikan & $\begin{array}{l}\text { Masa } \\
\text { Kerja } \\
\text { (thn) }\end{array}$ \\
\hline 1 & I.U 1 & 30 & $\begin{array}{l}\text { Koord } \\
\text { KIA }\end{array}$ & DIII Keb & 8 \\
\hline 2 & I.U 2 & 33 & $\begin{array}{l}\text { Koord } \\
\text { KIA }\end{array}$ & DIII Keb & 5 \\
\hline 3 & I.U 3 & 47 & $\begin{array}{l}\text { Koord } \\
\text { KIA }\end{array}$ & DIII Keb & 26 \\
\hline 4 & I.U 4 & 57 & $\begin{array}{l}\text { Koord } \\
\text { KIA }\end{array}$ & DIII Keb & 23 \\
\hline
\end{tabular}

Berdasarkan tabel 4.1 diketahui umur responden sebagian besar berumur diatas 30 tahun. Semakin cukup umur seseorang maka tingkat kematangan dan kekuatan dalam berfikir dan berkerja akan lebih matang. Dari segi kepercayaan masyarakat akan lebih percaya terhadap seseorang yang lebih dewasa, karena pada kategori umur ini seseorang akan memiliki kinerja atau tingkat prestasi yang tinggi.

Berdasarkan tabel 4.1 diketahu semua responden sudah memiliki kualifikasi pendidikan DIII Kebidanan. Pendidikan profesi bidan menurut KEPMENKES No 369/MENKES/SK/III/2007 tentang Standar profesi bidan yaitu lulusan Diploma III kebidanan, merupakan bidan pelaksana yang memiliki kompetensi untuk melaksanakan praktiknya baik di institusi pelayanan maupun praktik perorangan. ${ }^{8,9}$

Berdasarkan tabel 4.1 diketahui bahwa responden paling banyak menjalankan profesinya sebagai bidan dengan masa kerja lebih dari 10 tahun. Lama kerja seseorang menunjukkan 
bahwa pengalaman yang dimiliki sudah lebih banyak dan menguasai dalam memberikan pelayanan terutama dalam pelaksanaan pelayanan pemeriksaan kehamilan.

\section{Kesimpulan}

Sebagian informan utama telah mengikuti pelatihan ANC, Sarana dan prasaranan yang menunjang pelayanan antenatal di Wilayah kerja Dinas Kota Pekalongan sudah lengkap dan sesuai standar, namun ada beberapa alat yang kurang dimanfaatkan serta Pelaksanaan ANC Terpadu yang dilakukan oleh bidan telah efektif.

\section{Daftar Pustaka}

[1] Kementerian Kesehatan RI. Pedoman Pelayanan Antenatal Terpadu. Kementerian Kesehatan Direktur Jenderal Bina Kesehatan Masyarakat. 2010

[2] Kemenkes RI. Standar Antropometri Penilaian Status Gizi Anak. Jakarta: Direktorat Bina Gizi. 2011

[3] Badan Pusat Statistik. Survei Demografi dan Kesehatan
Indonesia (SDKI) 2007. Jakarta: Badan Pusat Statistik. 2007

[4] Sullivan, Amanda. 2009. Panduan Pemeriksaan Antenatal. Jakarta : EGC

[5] Saifuddin, AB. 2002. Pelayanan Kesehatan Maternal dan Neonatal. Yayasan Bina Pustaka Sarwono Prawirohardjo. Jakarta.

[6] Potter, Patricia A. dan Anne G. Perry. (2009). Fundamental Keperawatan Buku 1 Ed. 7. Jakarta: Salemba Medika

[7] Lincetto, Omella, dkk. Opportunities for Africa's Newborns. The Partnership For Maternal, Newborn and Childhealth: Africa. 2006

[8] Departemen Kesehatan Republik Indonesia. Keputusan Menteri Kesehatan Republik Indonesia Nomor 369/MENKES/SK/III/2007 tentang Standar profesi bidan. 2007

[9] Depkes RI. 2010. Prinsip Pengelolaan Program KIA. Jakarta: Depkes RI. 